\title{
Lumen
}

Selected Proceedings from the Canadian Society for Eighteenth-Century Studies

\section{Tom Jones and the Age of Discretion}

\section{Pat Rogers}

Volume 13, 1994

URI : https://id.erudit.org/iderudit/1012518ar

DOI : https://doi.org/10.7202/1012518ar

Aller au sommaire du numéro

Éditeur(s)

Canadian Society for Eighteenth-Century Studies / Société canadienne d'étude du dix-huitième siècle

ISSN

1209-3696 (imprimé)

1927-8284 (numérique)

Découvrir la revue

Citer cet article

Rogers, P. (1994). Tom Jones and the Age of Discretion. Lumen, 13, 1-12.

https://doi.org/10.7202/1012518ar d'utilisation que vous pouvez consulter en ligne.

https://apropos.erudit.org/fr/usagers/politique-dutilisation/ 


\section{Tom Jones and the Age of Discretion}

But well says a certain Author, No Man is wise at all Hours; it is therefore no Wonder that a Boy is not so.

Tom Jones, III.iv

One of the more obvious features about Tom Jones is the attention which Fielding gives to the precise passage of time. Book and chapter titles regularly chart the exact duration covered by a single section ('Containing the Time of a Year,' and so on). Perhaps the most significant of these markers is the one stretching over the longest span, that at the head of Book III: 'Containing the most memorable Transactions which passed in the Family of Mr Allworthy, from the Time when Tommy Jones arrived at the Age of Fourteen, till he attained the Age of Nineteen. In this Book the Reader may pick up some Hints concerning the Education of Children.' ${ }^{1}$ The narrator's belittling usage 'Tommy Jones' emphasizes the nearchildish state of the boy at fourteen; the rest of the time-span is explicitly that of teenage years. What may be concealed from us is that fourteen marked, in the most common legal definition, the onset of the years of discretion - more pervasively, though not uniquely, for boys.

We do not commonly think of Tom as a teenager, since most of the action, from Book IV onwards, relates to his early manhood. But it can scarcely be an accident that Fielding decides to 'bring forth our Heroe, at about fourteen Years of Age' $(1,118)$, since this coincides so precisely with the dawning of the years of legal discretion. Several commentators have suggested that the moral curve described by Tom is towards the attribute of prudence; but, as Swift indicated, prudence and discretion are not quite synonyms, and discretion may be the more appropriate concept. It may be added that Sophia is 'introduced into this History' when 'in her eighteenth Year' $(1,158)$. There is some ambiguity about this, since according to the usage of the day it could mean that she was either seventeen (as it would be nowadays) or eighteen. ${ }^{2}$ An earlier reference (III.x) puts her 'about seventeen years of age.' Either way she, too, enters the story as a teenager. ${ }^{3}$ 
Of course there was no real concept of a teenager in the eighteenth century. The simple word teens is not recorded in OED prior to Wycherley in 1673; probably the best known example from Fielding's era would be Garrick's play Miss in her Teens (1747), a conventional Old Comedy in essence centring on Biddy Bellair, a virgin of sixteen. In a broader sense, the teenage years correspond roughly with the stage of adolescence, which indeed was marked off in some of the many traditional ways of distinguishing the ages of man. ${ }^{4}$ According to certain definitions, adolescence extended in males until the age of twenty-five (having begun at fourteen), but in other versions the phase in both boys and girls was over by twenty-one. Even though the legal age of majority was long fixed at twenty-one, there remained lingering notions that maturity came a little later; perhaps the fact that in Roman law the age of inheritance was twenty-five helped to foster this attitude. But there was less argument about the start of adolescence, which was regularly placed around the onset of puberty, and that was almost routinely set at fourteen in boys.

But this particular moment in life, the one at which Fielding's hero enters the narrative, had a more precise significance than merely as the year which ushered in adolescence. It was, under English law, the age of discretion for both males and females. As Littleton's Tenures stated, 'The age of discretion is saide the age of xiii. yeares. ${ }^{5} \mathrm{~A}$ standard source in Fielding's own day, Giles Jacob's New-Law Dictionary, set out the understood position: 'At Fourteen, which is his Age of Discretion, he may consent to Marriage, and chuse his Guardian; and at Twenty-one he may alien his Lands, Goods and Chattels. ${ }^{6}$ A subsidiary right at the age of eighteen was the power of making a will, a fact to which Fielding refers in the Covent-Garden Journal, no. 3 (11 January 1752). Commentators such as Sir William Blackstone and Sir Robert Chambers (the latter possibly assisted by Samuel Johnson) devote space to questions surrounding legal majority and discretion. Their opinions occasionally differ in detail, but all concur in defining the years between fourteen and twenty-one as a kind of interim period from a legal standpoint. Certain rights and responsibilities inhere in males, especially, during this phase; the legal innocence of childhood is over, but full manhood has yet to be attained. At fourteen Tom Jones would have been deemed 'to be capable of exercising discretion or prudence' $(O E D)$. Whether he really was, at that age, every reader of the novel will regard as an open question.

The third of the Vinerian lectures by Robert Chambers (delivered 1767-73) provides a representative legal discussion. It occurs in a section, 'Of Exemption from Punishment,' where Chambers considers 'immaturity of discretion' as one factor (along with things like imbecility) which 
exempt an individual from conviction. He sets out the age categories used in Roman law. First, infantia, from birth to seven years; then pubertas, 'which begins at the completion of fourteen years' (the intermediate stage from seven to fourteen covered by subsidiary categories); and the pubertas plena, commencing at eighteen. A significant passage follows, describing the situation in English law:

Till seven we are infants and incapable of crime. At fourteen we become regularly answerable for moral activities, and at twenty-one are admitted to the full enjoyment of all social powers and civil rights; which the Romans were not till twenty-five. (328)

Thus English law conceived of infants as being incapable of felony. But the age-group from fourteen to twenty-one, while legally subject under criminal jurisdiction, might escape civil process, and indeed even in the criminal sphere might expect extra moderation and mercy if exposed to prosecution. The analysis shows, first, that the break which occurred in the Roman system at eighteen was postponed until twenty-one under English law. Subliminally this may make us think that Tom at eighteen would be allowed a measure of extra tolerance for his wilder actions. Second, it shows that even when a fourteen-year-old became responsible morally, this does not necessarily mean that he should be submitted to the full rigours of law. The whole section is about exemption from the criminal process. We could say that Tom Jones shows us the hero at the very outset as one just becoming subject to adult moral standards, and then progressing through the book to a stage where full adult identity is achieved. Early on he can claim exemption from the most searching standards of ethical judgment, but increasingly he has to move from a merely technical 'age of discretion' to a full human and legal responsibility for his own actions. It may be added that the sources Chambers drew on to assemble this survey would mostly be items familiar to Fielding from his training as a barrister.

It is worth comparing what Chambers says with the treatment of these issues by his predecessor, Sir William Blackstone, since there are significant differences in emphasis and even, at a detailed level, in factual statement. Blackstone covers the matter in book IV of his Commentaries (1765-9), on 'Public Wrongs,' with a chapter (IV.ii) devoted to 'The Persons Capable of Committing Crimes.' Like Chambers, then, Blackstone addresses the issue of legal infancy from the standpoint of potential culpability. 'Infancy,' in a very eighteenth-century fashion, is aligned with 'idiocy, lunacy, and intoxication,' as a circumstance producing a 'defect in will,' which precludes criminal responsibility. The initial ac- 
count which Blackstone gives is fuller and more precise than the corresponding passage in Chambers; he starts from Roman law.

First, we will consider the case of infancy, or nonage; which is a defect of the understanding. Infants, under the age of discretion, ought not to be punished by any criminal prosecution whatever. What the age of discretion is, in various nations is a matter of some variety. The civil law distinguished the age of minors, or those under twenty five years old, into three stages: infantia, from birth till seven years of age; pueritia, from seven to fourteen; and pubertas from fourteen upwards. The period of pueritia, or childhood, was again subdivided into two equal parts; from seven to ten and an half was ætas infantix proxima; from ten and an half was xtas pubertati proxima. During the first stage of infancy, and the next half stage of childhood, infantix proxima, they were not punishable for any crime. During the other half stage of childhood, approaching puberty, from ten and an half to fourteen, they were indeed punishable, if found to be doli capaces, or capable of mischief; but with many mitigations, and not with utmost rigor of the law. During the stage (at the age of puberty and afterwards) minors were liable to be punished, as well capitally, as otherwise. (22)

In his next paragraph, Blackstone immediately shifts to the qualifications of this cut-and-dried position which had been introduced by English common law. As often, it is not at once apparent to a modern reader how far the two systems of jurisdiction were in conflict, and indeed what kind of authority the older law still possessed. Be that as it may, the interpretation placed on infancy by the common law is plainly relevant to Tom Jones, where the hero is likely to run into the most basic form of justice at a local level:

The law of England does in some cases privilege an infant under the age of twenty one, as to common misdemeanors; so as to escape fine, imprisonment, and the like: and particularly in cases of omission, as not repairing a bridge, or a highway, and other similar offences: for, not having the capacity to do those things, which the law requires. But where there is any notorious breach of the peace, a riot, battery, or the like, (which infants, when full grown, are at least as liable as others to commit) for these an infant, above the age of fourteen, is equally liable to suffer, as a person of the full age of twenty one. (22-3)

One of the most obvious things about Tom is his tendency to get involved in any breach of the peace or riot going on within miles of his own location. Most of these affrays take place before he has reached the age of twenty-one. By the time he enters the story at fourteen, 'the lad [had]... already discovered a propensity to many vices... he had been already convicted of three robberies...' $(1,119)$. Ironic as the tone is, this 
introduction sets up Tom as a figure prone to indiscretion, and one liable to run into the clutches of the law. In the very same chapter, Tom is found guilty of poaching (the chief culprit, of course, is the gamekeeper Black George, though Tom refuses to betray his friend). When the truth comes out, Allworthy declares that 'the boy deserved reward rather than punishment' $(1,131)$ : the important point for our purposes is that, according to Blackstone's test, Tom would seem to be guilty of a crime within the meaning of the law, i.e. he would be deemed to have participated in an action for which he might be held responsible. This is all the more obvious in such episodes as the one in which Tom lays out Blifil and Thwackum in turn (V.xi), or the earlier scene where Tom, overjoyed at Allworthy's recovery from illness, gets into a drunken brawl with his cousin (V.ix). He had already given Blifil a bloody nose in response to name-calling (III.iv). Tom has still not attained his full majority, but he would certainly be regarded as 'full grown' from the point of view of criminal responsibility.

Finally, under this heading, Blackstone moves on to consider the capacity of a juvenile to commit felonies, and especially one of the wide range of capital crimes. (It should perhaps be noted that some of the risks Tom ran were those of transportation or imprisonment - for example, by the Waltham Black Act of 1722, which amended the Game Law of 1671 , most poaching was a felony liable to sentence of transportation: it was only poaching whilst armed or disguised that incurred the death penalty.) Blackstone defines the age of discretion here with characteristic precision:

With regard to capital crimes, the law is still more minute and circumspect; distinguishing with greater nicety the several degrees of age and discretion. By the antient Saxon law, the age of twelve years was established for the age of possible discretion, when first the understanding might open: and from thence till the offender was fourteen, it was ætas pubertati proxima, in which he might, or might not, be guilty of a crime, according to his natural capacity or incapacity. This was the dubious stage of discretion: but, under twelve, it was held that he could not be guilty in will, neither after fourteen could he be supposed innocent, of any capital crime which he in fact committed. But by the law, as it now stands, and has stood at least ever since the time of Edward the third, the capacity of doing ill, or contracting guilt, is not so much measured by years and days, as by the strength of the delinquent's understanding and judgment. For one lad of eleven years old may have as much cunning as anouther of fourteen; and in these cases our maxim is, that 'malitia supplet ætatem.' Under seven years of age indeed an infant cannot be found guilty of felony; for then a felonious discretion is almost an impossibility in nature: but at eight years old he may be guilty of felony. Also, under fourteen, though an infant shall be prima facie adjudged to be doli incapax; 
yet if it appear to the court and jury, that he was doli capax, and could discern between good and evil, he may be convicted and suffer death. Thus a girl of thirteen has been burnt for killing her mistress: and one boy of ten, and another of nine years old, who had killed their companions, have been sentenced to death, and he of ten years was actually hanged; because it appeared upon their trials, that the one hid himself, and the other hid the body he had killed; which hiding manifested a consciousness of guilt, and a discretion to discern between good and evil. (23)

Blackstone gives further instances: a boy of eight who had set fire to two barns, and a boy of ten who had murdered his bedfellow. Both were held to have had a clear consciousness of the crime, and to have displayed 'malice' in plotting it. They were accordingly convicted, as the judges regarded each as a proper subject of capital punishment. Blackstone evidently concurs, but he does add that in such cases the evidence of malice, 'which is to supply age,' ought to be 'strong and clear beyond all doubt or contradiction' (24).

What these passages from Blackstone show is that there was a certain grey area of moral responsibility among young people. But naturally the degree of tolerance decreased as the youth (it was generally a male) approached his majority. Moreover, 'the strength of the delinquent's understanding and judgment' is deemed crucial. Had Tom been a backward lad, he might have been able to plead some remission of punishment for his earlier indiscretions. In fact, as he lives in a magistrate's household, his lapses can be dealt with as a domestic matter; but such events as the poaching of the partridge were capable of landing a fourteen-year-old in court. But really Tom would have no defence along these lines. Fielding makes it clear that he is intelligent and aware. His understanding is not at fault, and his judgment is poor only because of his impetuous and over-generous character. Perhaps the most resonant phrase in Blackstone's discussion is his remark that 'one lad of eleven years may have as much cunning as another of fourteen,' a comment which might have been made with Blifil and Tom in mind. In one sense, Blifil has reached an 'age of discretion' long before Tom has passed well through boyhood.

However, Blifil himself once comes under question in respect of the very categories we have been considering. This occurs in the episode when he meanly 'frees' the pet bird which Tom had given to the thirteenyear-old Sophia (IV.iii), and especially in the inquest held upon this event by the adults (IV.iv). Square launches the debate by congratulating Allworthy on his nephew, 'who, at an Age when few Lads have any Ideas but of sensible Objects, is arrived at a Capacity of distinguishing Right from Wrong.' This is the official attitude of the book, ironized by the 
narrator. Thwackum disputes with Square how Blifil acquired this precocious sense of right and wrong, while the common-sensical Western reminds them that the boy had let the bird loose only for it to be taken by a hawk. To encourage boys in such practices, Western observes, is 'to breed them up to the Gallows'. Allworthy takes his usual judicial line, and concludes that Blifil had been wrong, but was culpable only to a small degree: the act was 'inconsiderate, and... only pardonable in a Child.' The two bigots continue to debate their charge, Square claiming that his principles have set young Master Blifil on a course for life: 'Young as he is, that Lad's notions of moral Rectitude, I defy you ever to eradicate.' The disputants call in 'a Gentleman of the Law, who was present,' but he merely spouts jargon. The last word in the scene is left to Squire Western, who commends Tom's bravery in trying to rescue the bird for Sophia. All this discussion plays around the idea of moral maturity: for the only time in the book, it is Blifil who is placed in the dock rather than Tom. In terms of the long-term implications of the story, this episode shows Blifil as one who has acquired a putative 'discretion,' evinced by his readiness to spout the moral platitudes of his seniors. Tom, 'a thoughtless giddy Youth, with little Sobriety in his Manner,' is still a long way from achieving even the simulacrum of such a state.

Two final observations may be made on the strict legalities underlying the novel. First, we can be absolutely sure that Fielding was conscious as he wrote of the age-markers which we have been discussing. As early as the first book, Allworthy remarks to Dr Blifil, 'My Sister, tho' many Years younger than I, is at least old enough to be at the Age of Discretion.' He adds that Captain Blifil had no need to request Allworthy's consent for his intended marriage with Bridget, 'since the woman is... Sui Juris, and of a proper Age to be entirely answerable only to herself for her Conduct' $(1,70)$. Secondly, it is worth remembering that Allworthy is acting as Tom's guardian throughout the hero's boyhood and adolescence. So much is clear from the episode at the start of the book (I.iv, v). Allworthy is said to have formed a resolution 'to take care of the Child, and to breed him up as his own'. Bridget, disgruntled, speaks of 'her Brother's Whim to adopt the little Brat.' In this era, wards came into notice chiefly in the person of rich young women without parents, and it was one aim of Hardwicke's Marriage Act to protect this group. But the law extended protection to male wards as well, and indeed under Roman law wards (both male and female) who were above the age of puberty but under the age of twenty-five were considered minores, and they continued to be subject to the rule of their guardians. Moreover even one sui juris (i.e. beyond puberty) who was still under twenty-five needed the consent of a parent in order to be married - a situation not replicated in English law. What this means is that Tom, whilst he was 
under the guardianship of Allworthy, was hemmed in by a large body of civil law, defining his rights explicitly in terms of age. The law did not grant him full maturity until twenty-one (despite his liability in appropriate cases, as seen in the excerpt from Blackstone). It would therefore be a harsh moral code which would expect him, in the first portion of the novel, to act with true adult authority and discretion.

\section{II}

What was true in the legal sphere applies to a considerable extent in a broader moral arena. By extension the 'year of discretion' came to mean the arrival of maturity, when an individual was in a condition to display $O E D$ 's wider definition, 'Ability to discern or distinguish what is right, befitting, or advisable, esp. as regards one's own conduct or action; the quality of being discreet; discernment; prudence, sagacity, circumspection, sound judgement.' If we relate this to Tom Jones, it is apparent how a complex fiction will muddy the neat categories of a lexicographer. Tom has some natural ability to discern what is right, rather less what is befitting, scarcely any ability in respect of what is advisable. He has a degree of innate sagacity perhaps, and a modicum of judgment. But it is part of his attraction (to Fielding, to Sophia, and to most readers) that he is not discreet, and if he can claim some discernment he is defiantly without any circumspection. Self-evidently, it is Blifil who exhibits the latter quality. It is noteworthy, too, that the contrast between the two youths is made explicitly at the age of sixteen (III.v). Johnson's definition of the key term, published within a decade of the appearance of Tom Jones, again points to Blifil's approach to life: 'Prudence; knowledge to govern or direct one's self; skill; wise management.' Numerous passages indicate the self-control which enabled Blifil, unlike the younger Tom, to bide his time until the right moment should present itself for his purposes: the last paragraph of VI.x $(1,308-9)$ provides a sustained example. Lacking the 'naturally violent animal spirits' which Tom possessed (V.ix), Blifil could regulate even the modicum of desire he felt for Sophia 'by Philosophy or Study, or by some other Method' (VI.iv). And his eye for his own self-interest undercuts ironically the $O E D$ references to the 'ability to discern... what is... advisable... as regards one's own conduct.' Fielding seems proleptically to have satirized this way of defining.

Johnson's entry in the Dictionary ends with a citation from Swift: 'There is no talent so useful towards rising in the world or which puts men more out of the reach of fortune than discretion, a species of lower prudence.' This is an abbreviated version of the opening sentence in 
Intelligencer no. 5 (c. 8 June 1728), a paper devoted to that 'lower kind of discretion and regulation' which, Swift observed elsewhere to Bolingbroke, ensured worldly success. ${ }^{8}$ For Swift, this inferior attribute goes with parsimony, lack of imagination, sycophancy and self-interest. Its possessors should be debarred from any public office requiring the higher talents of 'Genius, Learning, strong Comprehension, quickness of Conception, Magnanimity, Generosity, Sagacity, or any other superior Gift of Human minds. ${ }^{9}$ (We may observe how 'sagacity', which Tom could perhaps claim, has changed sides.) The wider point is that Swift drives a wedge between socially approved 'discretion' and genuine moral awareness. In the same way Fielding appears to make a distinction between what the world identifies as discretion, something taken to unpleasant extremes by Blifil, and prudence, a quality Tom initially lacks but must in some measure come to attain. To put the matter in this way, of course, is to make the fable seem crudely moralistic; but that is the reductive consequence of critical analysis, rather than any actual defect of the novel itself.

There can be no doubt that Fielding was fully aware of the legal implications of the concept of discretion: but even this legal notion was inescapably moral in its bearings. This can be seen from the famous manual by Richard Burn, The Justice of the Peace, and the Parish Officer, a work first issued in the year after Fielding's death and published by his own bookseller Andrew Millar. Burn observes, 'It is said generally, that those who are under a natural disability of distinguishing between good and evil, as infants under the age of 14 years, which is called the age of discretion, are not punishable by any criminal prosecution whatsoever. But.... in general it must be left to the discretion of the judge, upon the circumstance of the case, how far an infant, under that age, is capax doli, or hath knowledge to discern between betwixt good and evil. ${ }^{10}$ At first sight here we may suppose Burn's use of the term in 'discretion of the judge' to be a mere accidental pun, but this may not be so. We could certainly argue that Fielding the narrator exercises a constant right of discretion in dealing with his characters. Tom is ultimately saved from the gallows, not just out of some overriding providential thematics in the novel, but because Fielding the humane magistrate can see the virtues of his defects - the sagacity which shines through his indiscretions, just as there is a total absence of true moral discernment hidden beneath Blifil's ostensible 'prudence.'

'We wild girls always make your prudent wives and mothers,' Lady Mary Wortley Montagu (Fielding's kinswoman) once wrote to her sister Lady Mar. ${ }^{11}$ This is an application of the old proverb, 'Young saint, old devil'; in a highly pertinent essay, J.A. Burrow has shown how this maxim underlies the situation around Tom and Blifil. ${ }^{12}$ It is enough here 
to add that Tom's crucial experiences occur when he is arriving at full manhood, and attaining more than formulaic powers of discretion. At the very end we are told, '[Tom] hath also, by Reflexion on his past Follies, acquired a Discretion and Prudence very uncommon in one of his lively Parts' $(2,981)$. Discretion and prudence have finally merged. This is the kind of closing utterance which some readers find unconvincing, but Fielding has worked to make it less pat and contrived through the important scene of reconciliation between Tom and Sophia (XVIII.xii). The key terms explored here are not used in that scene, but insofar as Tom is called on to justify his repentance, his change of heart and his new 'constancy,' the same underlying ideas are adumbrated.

Martin Battestin, in one of the few studies which seize directly on the issue of age, makes this comment on the Man of the Hill episode: 'To invoke the Aristotelian notion of the "Three Ages of Man," at this juncture in Tom's progress towards maturity he is presented with the extreme alternatives of youth and age - the roughness and passion which characterize his own adolescence... as opposed to the worldly cynicism of the Old Man of the Hill. ${ }^{13}$ There is some obvious truth in this comment, but in general Fielding does not seem to have been operating in the simplest triad of the Ages of Man (augmentum/status/decrementium, as Latinized in the medieval period). On this scheme, as in Dante, adolescence represents an unbroken spell of growth, from birth to twenty-five; old age runs from forty-five to seventy. In theory the Man of the Hill must be almost ninety, since he was born in 1657 and the action clearly takes place around the time of the 1745 Rebellion; but such extreme senility is not a major part of his characterization in practice. He is notable more for his strange appearance and behaviour, his reclusive ways and his excessive misanthropy. When Tom retorts that 'I have lived but a short Time in the world, and yet have known Men worthy of the highest Friendship, and Women of the highest Love' $(1,485)$, we can scarcely doubt that his views are endorsed by the author. It is tempting to see the old man's misfortunes in sexual encounters as part of the theme of the passage of love, in which traditionally the senex figure might look back philosophically on the passions of youth. But Fielding's old man has more of the weaknesses than the received virtues of the senex, and in general seems not quite to fit into the usual ages-of-man scheme.

Within his fictional plan Fielding needs at the very least four stages, including a separate phase of childhood for little 'Tommy Jones.' Only in this way can he emphasize the critical phase of youth, and as I have tried to show it is the teenage years (after legal discretion has set in, but before mature prudence has emerged) which define Tom's position, especially in the first block of six books prior to his expulsion from Paradise Hall. Fielding constantly appeals to nature as his touchstone, 
and as Burrow has revealed, it was as infractions against nature that young saints and old devils were equally suspect. The learning curve Tom describes is one appropriate to a very young man, only just emerging from adolescence; his cursus ætatis is almost that of the average young man, at least as compared to that of Blifil.$^{14}$ He needs, in fact, to grow up - in a particular and sharply defined sense of that phrase which we have largely forgotten today. It is time for him to move from the nominal years of discretion to the actual state of discretion, 'the quality of being discreet; discernment; prudence... sound judgement.' By the end Sophia and Fielding, at least, believe he has done so.

\section{PAT ROGERS}

DeBartolo Chair in the Liberal Arts

University of South Florida, Tampa

\section{Notes}

1 Henry Fielding, The History of Tom Jones, ed. Martin C. Battestin (Oxford: Clarendon Press, 1974), 1, 116. All references are to this edition, and are supplied in the text: page references in the form '1, 200,' and chapter references as 'III.vi.'

2 On the difficulties of interpreting age precisely in historical sources, see the seminal article by Keith Thomas, 'Age and Authority in Early Modern England,' Proceedings of the British Academy, 62 (1976), 205-48, esp. 206-7. See also, on the former lack of precision in counting people's ages, J.H. Plumb, 'Children, the Victims of Time,' In the Light of History (Boston: Houghton Mifflin, 1973), p. 154. Hester Thrale was one who regularly miscalculated (by modern standards) her true age: see James L. Clifford, Hester Lynch Piozzi (Mrs Thrale) (Oxford: Clarendon Press, 1965), pp. 269, 450. As Clifford points out, Samuel Johnson counted his 'first' birthday as his second, and so on for later birthdays.

3 I have not discussed Sophia's role at length in this essay. The standard sources such as legal commentaries are much less full and explicit on girls, and most of the ways of describing the ages of man are literally that. It is, however, a subject worthy of separate discussion. (Normally the age of consent to marriage was set for girls at twelve.)

4 The most helpful recent discussion is that of J.A. Burrow, The Ages of Man: A Study in Medieval Writing and Thought (Oxford: Clarendon Press, 1986).

5 Quoted in OED, 'Discretion,' 6b.

6 Quoted in B.A. Goldgar (ed.), The Covent-Garden Journal and A Plan of the Universal Register Office (Oxford: Clarendon Press, 1988), p. 29. It may be added that, in the last two years of Fielding's life, the Marriage Act of 1753 established twenty-one as the age at which both men and women were able to marry without parental consent. See Lawrence Stone, Road to Divorce: England 1530-1987 (Oxford: Oxford University Press, 1990), pp. 121-8. 
7 William Blackstone, Commentaries on the Laws of England (Oxford, 1765-9), IV, 22-4; Robert Chambers, A Course of Lectures on the English Law, ed. T.M. Curley (Oxford: Clarendon Press, 1986), I, 328-31. In his Dictionary, Johnson quotes s.v. 'Age,' 7, John Cowell's Interpreter (1607); 'In a man, the age of fourteen is the age of discretion; and twenty-one years is the full age.... At the age of fourteen, a stripling is enabled to choose his own guardian... [and] may consent to marriage.' Statements regarding Roman law are based chiefly on H.F. Jolowicz, Historical Introduction to Roman Law (Cambridge: Cambridge University Press, 1965).

8 The Intelligencer, ed. James Woolley (Oxford: Clarendon Press, 1992), p. 78: see also the following issue, no. 7 (p. 95 ff.). The Correspondence of Jonathan Swift, ed. H. Williams (Oxford: Clarendon Press, 1963-5), II, 332-3.

9 Intelligencer, ed. Woolley, p. 79.

10 Quoted from Burn's Justice of the Peace (10th ed., 1766), II, 446-7, by Bertram H. Davis, The Proof of Eminence: The Life of Sir John Hawkins (Bloomington: Indiana University Press, 1973), p. 213.

11 The Complete Letters of Lady Mary Wortley Montagu, ed. R. Halsband (Oxford: Clarendon Press, 1965-7), II, 57.

12 J.A. Burrow, '“Young Saint, Old Devil": Reflections on a Medieval Proverb,' in Essays on Medieval Literature (Oxford: Oxford University Press, 1984), pp. 177-91. I am grateful to Professor Burrow for his comments on a draft of this paper, and also to MaryBeth Gugler for her useful suggestions. For play with other proverbial expressions, such as 'Grey hairs look odious on a green Head,' see The Covent-Garden Journal, ed. B.A. Goldgar (Oxford: Clarendon Press, 1988), p. 307.

13 M.C. Battestin, 'Fielding: The Definition of Wisdom,' in The Providence of Wit (Oxford: Clarendon Press, 1974), p. 189.

14 In Ptolemy's scheme, relating each phase of life to the influence of a single planet, the years of fourteen to twenty-one were ruled by Venus, after which 'the lord of the middle sphere,' the sun, took over: see Burrow, Ages of Man, pp. 197-8. It hardly needs to be said that Tom, and the general course of the narrative, fall neatly into place here. 